\title{
The role of mobile learning on the learning environment shifting at high school in Indonesia
}

\section{Dwi Sulisworo* and Moh Toifur}

Physics Education Department, Ahmad Dahlan University, Jl. Kapas No. 9, Yogyakarta, Indonesia

Email: dwi.sulisworo@uad.ac.id

Email: mtoifur@yahoo.com

*Corresponding author

\begin{abstract}
This research is the result of a multi-year research since 2013-2015, which aims to determine the shifting of learning environment associated with the development of mobile technology. The rapid changing on information technology has affected the current learning strategy. The analysis of this study is a qualitative descriptive approach. The result indicates that mobile technology shifted the tendency of students to learn in a more personalised way. This situation encourages teachers to be able to choose and use technology for students learning success. The implication of this research is that the teachers, students and schools will need to have a different role than before to adapt the changing in today's learning environment. More focus again, learning design needs to enable cooperative learning in a mobile for the convenience of studying individually. In the implication of this research, there is a shifting of learning environment due to mobile technology.
\end{abstract}

Keywords: collaborative; cooperative learning; education technology; learning management system; mobile learning; physics education.

Reference to this paper should be made as follows: Sulisworo, D. and Toifur, M. (2016) 'The role of mobile learning on the learning environment shifting at high school in Indonesia', Int. J. Mobile Learning and Organisation, Vol. 10, No. 3, pp.159-170.

Biographical notes: Dwi Sulisworo is a Senior Lecturer at the Graduate Program of Physics Education Department, Ahmad Dahlan University, Indonesia. His research interest is in the educational technology especially on learning strategy using information and communication technology. His current research is related to the mobile technology for student learning improvement.

Moh Toifur is a Senior Lecturer at the Graduate Program of Physics Education Department, Ahmad Dahlan University, Indonesia. His research interest is in the physics instrumentation as well as for learning.

\section{Introduction}

Mobile technology development and its business become move rapidly in recent years. Its cost is cheaper and cheaper than before with increasing capacity and capability. As found from some previous studies, digital mobile technology has given new possibility 
and opportunity for the new learning perspective, including the relation between teacher, students, and the learning material. Considering the technology development and the research result on motivation, appreciation to the learning interest, and the usage of learning media, learning is more fruitful. Learning becomes more variative approaches. The problems in some countries, including Indonesia, are the teacher's literacy on information technology and learning strategies. It affects the ineffective learning environment using information technology (Mohammad et al., 2015; Pullen et al., 2015).

Mobile learning is a consequence of the increasing information and communication technology development. This will also affect the shift of learning environment. The new pedagogical models are needed to guide the development of learning systems (Aresta et al., 2015; Bhardwaj and Jain, 2015; Grimus and Ebner, 2015). Information technology and mobile communication is essential to enable the formation of a new social structure in learning (Zagami, 2015; Brown and Mbati, 2015). By using this new model, it can be developed a variety of mobile learning strategies and approaches that can drive the success of learning (Anders, 2015; Jansen et al., 2015; Furió et al., 2015). Some research reports showed the success of mobile technology implementation on learning in many countries, such as Malaysia (Gan and Balakrishnan, 2016), Taiwan (Chen, 2015), Saudi (Alfarani, 2015), Oman (Sarrab et al., 2015), Ghana (Grimus and Ebner, 2015), and Europe (Jansen et al., 2015).

In looking at the shift in this new learning environment, there are some aspects which are variables in learning to be considered, i.e. a learning strategy, motivation, interest in learning, information technology literacy, gender, economic background, and learning outcomes. The aim of this study is to figure out how these variables interact associated with the development of information technology. The end result is an overview of the shifting of learning environment that should be anticipated in order to obtain an optimum learning environment for student growth.

\section{Literature review}

There are many aspects to be considered in the learning model development. The first is the mobile technology improvement. Mobile devices are generally small, portable and compact. This device is more suitable for a pocket or purse. Mobile devices are relatively cheaper, lighter, and can be used for a long time because of power efficient or may use disposable batteries or recharge. Smaller screen size on mobile devices can be received because of the emergence of various mobile devices which also provide a wide screen for user convenience. Some of these devices have good audio that allows students to repeat the course material instead of reading material on the screen. In a new development, the tool is more adaptable to various needs of users that can be used in e-learning and also makes it possible to send large amounts of information quickly, something unavailable in a conventional computer. Now, many instructional developers and educators have been examining the effectiveness of mobile devices and their features on learning (Huang and Chiu, 2015; Chen, 2015; Muchlas, 2015; Sung et al., 2015; Pullen, 2015).

The second is constructivism as a learning paradigm. The integration of technology in learning can enhance the learning experience. M-learning provides an opportunity for students to stay involved in their learning environments that cannot be obtained through 
static technology devices such as desktop computers. Now, a change in the philosophy of teaching and learning has been moving from a teacher-centred learning into a student-centred approach. Muchlas (2015) found that online collaborative teaching model for digital technique practical work showed positive impact on both the learning achievement and perception. This result is parallel to the research conducted by Chen (2015) that Web 2.0 using mobile Facebook on collaborative activities (discussion and problem solving assignment) improved student learning performance. Srisawasdi and Sornkhatha (2014) also found that mobile learning using simulation-based inquiry approach enhanced students' conceptual learning. Sarrab et al. (2015), Sung et al. (2016), and Gan and Balakhrisnan (2015) wrote more comprehensive analysis related to constructive roles of mobile learning.

Those researches showed that mobile technology gives more possibilities to improve the quality of teaching in many aspects. The ability of students to actively construct knowledge, rather than the more passive in response to a tutorial action, is essential in the new learning approach. Constructivism learning approach encourages thinking explicit learning, reasoning, encourage effective problem-solving and planning skills, learning to learn from mistakes, and developing reflective meta-cognitive skills. The common understanding of constructivism is that by actively trying to make something concrete (physical or computational) to solve the problem. Articulation and reflection on their thinking whether it is working or the necessary revisions are common in the constructivist approach. Teachers and students must engage in active dialogue. Effective methods for structuring knowledge should result in at simplifying, generating new propositions, and increasing the manipulation of information. There are three main principles in learning approaches which should focus on experiences and contexts that make the student willing and able to learn (readiness), instructions should be structured so that it can be easily captured by the students, and learning needs to be designed to facilitate extrapolation and to fill the gaps of understanding.

The third is the interaction between the components of m-learning. M-learning components include hardware, students, and social aspects (Ally and Prieto-Blazquez, 2014). Shroff et al. (2015) stated that mobile application in a learning environment did not change the essential aspects of student learning, but the interaction of its components makes student more flexible in learning. Attributes of the usefulness of the device and the intersection of social technology illustrate the affordances of mobile technology. Intersection labelled learning interaction contains theories of learning and teaching with an emphasis on social constructivism (Kwan and Wong, 2015; Brengartner et al., 2015), the third aspect of the overlap at the main intersection. Hypothetically, a major intersection is, the convergence of these three aspects, to define mobile learning ideal situation. Aspects that should be taken into account are: (1) aspects of the device that refer to the physical characteristics, technical, and functional from mobile devices (Lee et al., 2015; Looi et al., 2015); (2) aspects of learners including the individual cognitive abilities, memory, knowledge, emotions, and perhaps motivation. This aspect explains how students use what they already know and how they encode, store, and transfer information (Kent et al., 2016; Hasyim et al., 2015); and (3) the social aspect associated with and explain the process of social interaction and cooperation (Sung et al., 2015; Alfarani, 2015; Brown and Mbati, 2015): while someone joining a new community, he must share the customs and culture of their own and learned people of the new community. 
Mobile learning is effective to provide improved cognitive environment in which distance learners can interact with the teacher, course material, physical and virtual environments, and one another (Alabdulkareem, 2015; Montrieux et al., 2015; Kent et al., 2016). Educators need to respond with more flexible methods of knowledge management in order to prepare students to navigate in an information-rich world. Because the process of mobile learning is defined by social factors, cognitive, environmental, and technologies, mobile learning can help students gain direct access and sustainable to information, colleagues, and experts who can help them determine the relevance and importance of the information found on the second internet and their realworld environment.

Cooperative learning is an umbrella term for a set of teaching strategies designed to teach teamwork and interaction among students. The objectives of cooperative learning include at least three aspects, which are the result of academic learning, acceptance of diversity, and the development of social skills. This strategy refers to the theory of Vygotsky, which emphasises social interaction as a mechanism to support cognitive development (Davidson et al., 2014; Herman and Pinard, 2015; Lam, 2015; Hằng et al., 2015). Moreover, this method is also supported by learning theory and the cognitive information processing theory of learning. The implementation of this learning theory will help students proceed the information more easily because the encoding process is supported by the interactions emerging in cooperative learning activities (Sharan, 2015; Andersson et al., 2015; Jacobs, 2015; Tadesse and Gillies, 2015).

There are many learning models in cooperative learning. Some of them that used on this research are Jigsaw, Reverse Jigsaw, Group Investigation, Two Stay Two Stray, Team Game Tournament, Pairs Group, Guided Discovery, Prediction-ObservationEvaluation technique, and Science Learning Cycle. These models have same principles of cooperative learning but they are different in the learning setting and procedure. Cooperative learning-instructional methods have benefits when they were applied on learning (Mehta and Kulshrestha, 2014; Sulisworo and Suryani, 2014; Huang et al., 2015; Salam et al., 2015; Gull and Shehzad, 2015). The goal of cooperative learning is to create a situation where individual success is determined or influenced by the success of the group. By the more sophisticated information technology improvement, many researchers have concern on how to implement this learning strategy using mobile technology for better learning performance (Lam, 2015; Huang et al., 2015; Huang and Chiu, 2015; Land and Zimmerman, 2015; Hwang and Shih, 2015).

\section{Method}

This research was conducted from 2013 to 2015 with the funding from the Ministry of Research, Technology and Higher Education, Indonesia. In the implementation of this study involved 14 secondary schools and vocational high schools both in Yogyakarta, Wonosobo, Cilacap, Bantul, Ternate, Purworejo, Brebes, Bangkalan, Bima and Sleman. The research applied purposive sampling technique for selecting the research area. The sampling technique used cluster sampling technique. This research study used a quasiexperimental research method with a model of pretest-posttest control group design. Statistical analysis techniques used are ANOVA, ANACOVA, or MANACOVA that depend on the variables. The grouping structure of this study is shown in Table 1. 
Table 1 Grouping structure of activities

\begin{tabular}{|c|c|c|c|}
\hline & Year I & Year II & Year III \\
\hline $\begin{array}{l}\text { Place } \\
\text { (districts) }\end{array}$ & $\begin{array}{l}\text { Bantul, Purworejo, } \\
\text { Yogyakarta }\end{array}$ & $\begin{array}{l}\text { Bangkalan, Bima, } \\
\text { Wonosobo, Brebes }\end{array}$ & $\begin{array}{l}\text { Ternate, Sleman, Cilacap, } \\
\text { Yogyakarta }\end{array}$ \\
\hline $\begin{array}{l}\text { Learning } \\
\text { strategies }\end{array}$ & $\begin{array}{l}\text { Two Stay Two Stray, } \\
\text { Jigsaw, Reverse Jigsaw, } \\
\text { Team Game } \\
\text { Tournament, Group } \\
\text { Investigation }\end{array}$ & $\begin{array}{l}\text { Science Literacy Cycle, } \\
\text { Group Investigation, } \\
\text { Prediction-Observation- } \\
\text { Evaluation, Pairs Group }\end{array}$ & $\begin{array}{l}\text { Personal Learning } \\
\text { Environment, Group } \\
\text { Investigation, Drill and } \\
\text { Practice, Guided Discovery }\end{array}$ \\
\hline $\begin{array}{l}\text { Learning } \\
\text { management } \\
\text { system or } \\
\text { LMS }\end{array}$ & $\begin{array}{l}\text { Classroom direct } \\
\text { learning }\end{array}$ & $\begin{array}{l}\text { Blog, Moodle, } \\
\text { customised LMS }\end{array}$ & $\begin{array}{l}\text { Path, Edmodo, } \\
\text { Blog, Facebook }\end{array}$ \\
\hline $\begin{array}{l}\text { Number of } \\
\text { students }\end{array}$ & 142 & 143 & 215 \\
\hline Male & 70 & 64 & 102 \\
\hline Female & 72 & 79 & 113 \\
\hline Method & \multicolumn{3}{|c|}{ Pretest-posttest control group design } \\
\hline
\end{tabular}

In this paper, the researchers used a qualitative descriptive method to analyse the data. The research was conducted in some schools implementing different learning strategies both online and in the classroom.

\section{Result and discussion}

\subsection{Result of year I}

From preliminary study, there were some important things recorded. Observation on information technology literacy of students (2012) did not show a significant impact towards student learning achievement. It showed paradoxical situation. Further elaboration found two factors that led to a paradoxical situation. The first is the students have had literacy in information technology, but the school is not yet supported by the teacher's ability to utilise this technology in learning. Meanwhile, the availability of learning content on the internet is easily understood by students (it means there is language limitation of student).

The first year of research was held in Yogyakarta (one school applied Two Stay Two Stray strategy), Purworejo (two schools applied Jigsaw Learning and Team Game Tournament strategies), and Bantul (one school applied Reverse Jigsaw Learning strategy). The independent variable was learning strategy, gender and economic background. The predictor variables were motivation and information technology literacy. The dependent variable was learning achievement and learning interest. In Yogyakarta, the quasiexperiment was applied with pretest-posttest control group design. The result showed that economic background, gender and information technology literacy did not affect significantly to the student achievement. The learning strategy significantly affected the students' achievement. Other researches in Bantul and Purworejo showed the same result. 
In this study, the economic background was observed in urban areas (Yogyakarta) and also in the districts (Bantul and Purworejo). The main factor contributing to the success of student's learning is the motivation to learn. The research showed that the learning achievement can be predicted from the motivation. The higher motivation drives to better learning achievement, and vice versa. The interest towards learning material is also influenced by learning strategies. Variance analysis on the average score of learning achievement (pretest and posttest) between classes taught using cooperative learning approach and direct learning approach was significantly different. The class taught by cooperative learning strategies tended to have a higher attainment as well as higher learning interest.

Based on the results of year I, the research at the second year excluded variables of economic background and gender. In accordance with the objectives of this study, then in the second year would focus to describe how the implementation of online cooperative learning can improve students' learning achievement. This is as an anticipation to the high level of students' information technology literacy, but inadequately facilitated by school's management. Meanwhile, schools should increase teacher's awareness to technology and more available learning content in cyberspace in early 2013.

\subsection{Results of year II}

In the second year, the research carried out with a focus on the use of the internet for learning. There are four research conducted in this year using some learning strategies, namely Science Literacy Cycle (SLC) using Blog at Bangkalan, Group Investigation (GI) using Mobile Moodle at Bima, Prediction-Observation-Evaluation (POE) at Wonosobo, and the Pairs Group at Brebes using other learning strategies. The schools chosen have represented the suburban areas. The reason is to figure out whether the online cooperative learning can be applied effectively in a wider area or not.

The independent variable in this study was a learning strategy. In the control group, the researchers applied conventional learning, while in the treatment group was online cooperative learning. The predictor variables were the prior knowledge and motivation as covariates. The dependent variable was the learning achievement. In certain experiments, the students' involvement was studied. The research design was same as the first year's research, i.e. quasi-experiment using pretest-posttest control group. Based on the experience of the first year study, the researchers assumed that students have had good information technology literacy.

Results of the second study showed that the prior knowledge can be used as a predictor to the success of student learning. It means the students who have a good prior knowledge will tend to have good learning achievement. The same result was found for the students' motivation variable. These results were still relevant and in accordance with the results of the first year. The learning strategies gave significant influence on student learning achievement, in which the students taught using online cooperative learning would have higher learning achievement than students taught using conventional learning.

From the four studies at schools conducted in the second year, it can be concluded that information technology will increase the effectiveness of learning. Students' learning achievement would be better by using this new approach. There were several factors that 
need to be considered in the implementation of online cooperative learning, including the availability of sufficient material and the intensity level of interaction by leveraging existing media. It was seen that the use of static media like Blogs tends to have lower efficacy compared with other media such as Moodle. But teachers have a limitation here. The use of Moodle is too complex to exceed the necessary requirements in learning.

\subsection{Results of year III}

In the third year, the study is almost the same as in the second year. The only difference was in the type of learning management systems used. In this year several social media were used, such as: Path at Ternate, Facebook at Sleman and Yogyakarta, and also Edmodo at Cilacap. Variables used were still the same. The independent variable in this study was learning strategy. The conventional learning used by teachers currently was applied in the control group. The treatment group applied online cooperative learning. The predictor variables as covariate were prior knowledge and motivation of students. The dependent variable was the learning achievement and learning interest.

In general the result of the third year was almost the same as to the second year. The online cooperative learning strategies could significantly increase students' learning achievement. Comparing to learning strategy used in the study, it did not show different result significantly. It means that Edmodo or Facebook or Path does not have much effect on students' learning success. However, compared to conventional learning practising direct lesson instruction in the classroom, online learning tends to increase students' interest in learning. Urban or suburban differences were not significant influence on student learning outcomes. This means that the online cooperative learning can be applied effectively in all regions. In general, it can be said that online learning can facilitate learning individually and for cooperative learning model. Availability of learning content is really attracting students' interest on learning. In addition, the mobile technology also supports the students to access learning resources online more easily.

\subsection{Discussion}

From the results of several years of research above, there is a shifting of learning environment due to mobile technology. This shift is driven by some major aspects, namely (1) the virtualisation phenomenon, (2) a theme-based learning, and (3) personal learning. The shift to a theme-based learning is supported by a number of various learning resources. It allows the development of learning as a base for research focus. This focus can increase motivation and interest in learning in a particular subject matter.

Information technology has facilitated a variety of new learning approaches that allow students to develop their learning interest naturally. They can find a wide range of knowledge through independent thinking and real-world experience that lead to personal learning. In a personal learning environment, there are some aspects to be considered, especially in the independent learning and the ability to manage individual learning, or called self-regulated learning. Also, it should be noted that the increasing responsibility and control that exist in students do not necessarily equate to an increase in their motivation. Their active role in navigating in cyberspace helps them make a decision about how to look for, where to look, and what to select content related to their business. 
Thus, it also increased their understanding to the particular competence. These results support other researchers concerning on the mobile technology enhancing learning. For example, Hasyim et al. (2015) reported that gender did not give effect to mobile learning adoption but cognitive, affective and social needs. Furió et al. (2015) also reported the same result when they studied the satisfaction aspect regarding gender; Yau and Leung (2016) related to attitude and self-efficacy in mobile learning; Faqih and Jaradat (2015) found that gender did not have moderation effect.

From this research, it can be concluded that mobile learning has possibility to improve learning quality more effectively and efficiently. Researches conducted at second and third year showed the learning strategy had effect to students' learning achievement in several aspects or variables, not only on learning material improvement, but also on creativity, interest, responsibility, and social skills. The combination of cooperative learning and mobile learning mutually gave the better new learning environment (Sung et al., 2015; Reychav and Wu, 2015; Fulantelli et al., 2015). Based on the research results, the new learning environment can be modelled. Changes on conditions in the learning environment encourage the importance of a more personalised approach to learning. This result was also mentioned by Cervera and Johnson (2015), Farajollahi et al. (2015), Bray and Tangney (2016), and Lai and Hwang (2015). With this new learning approach, it is possible to determine their destination independently and to design a good learning strategy associated with learning, learning targets, learning resources, peer learning, teaching materials, and various other elements, in order to build more convenient interaction and build motivation (Brown and Mbati, 2015; GarcíaPeñalvo and Conde, 2015; Huang and Chiu, 2015; Powell and Wimmer, 2015).

\section{Summary}

During three years research in different districts, there are many opportunities of the mobile learning implementation. The high number of mobile technology penetration in Indonesia should be used to support education quality improvement. Students in all districts have had a good information technology literacy; therefore, this literacy did not affect the students' learning performance. The economic background and gender did not affect the student's learning performance either. As shown in this research, cooperative mobile learning strategy affected the improvement of the students' learning performance and achievement. Moreover, the students' learning motivation was the most important for the learning success. It could be used to predict whether students would successful or not in their learning. The criteria of learning success will be shifted due to the rapid increase in information technology. Changes in learning environments and interactive learning applications in m-learning components will affect the strategies and approaches to students' learning in order to facilitate student's success. These implications should be considered by the school management as decision-making. The learning in future will tend to be activities that are more personal or personal learning networks that allow interregional become premises of various skill levels. 


\section{References}

Alabdulkareem, S.A. (2015) 'Exploring the use and the impacts of social media on teaching and learning science in Saudi', Procedia - Social and Behavioral Sciences, Vol. 182, pp.213-224.

Alfarani, L.A. (2015) 'Influences on the adoption of mobile learning in Saudi women teachers in higher education', International Journal of Interactive Mobile Technologies, Vol. 9, No. 2, pp.59-62.

Ally, M. and Prieto-Blazquez, J. (2014) 'What in the future of mobile learning in education? Mobile learning application in higher education', RUSC Universities and Knowledge Society Journal, Vol. 11, No. 1, pp.142-151.

Anders, A. (2015) 'Theories and application of Massive Online Open Courses (MOOCs): the case for hybrid design', International Review of Research in Open and Distributed Learning, Vol. 16, No. 6, pp.39-61.

Andersson, A., Wiklund, M. and Hatakka, M. (2015) 'Emerging collaborative and cooperative practices in 1:1 schools', Technology, Pedagogy and Education, Örebro University, Sweden, pp.1-18.

Aresta, M., Pedro, L. and Santos, C. (2015) 'Mobile learning and higher education: a theoretical overview', Journal of Mobile Multimedia, Vol. 11, Nos. 1-2, pp.147-156.

Bhardwaj, R.K. and Jain, R.K. (2015) 'Research trends in mobile learning: a global perspective', Collnet Journal of Scientometrics and Information Management, Vol. 9, No. 2, pp.205-224.

Bray, A. and Tangney, B. (2016) 'Enhancing student engagement through the affordances of mobile technology: a 21 th century learning perspective on realistic mathematics education', Mathematics Education Research Journal, Vol. 28, No. 1, pp.173-197.

Brengartner, V., Magelhaes, J.F. and Menezes, C.S. (2015) 'Adaptation resources in virtual learning environment under constructivist approach: a systematic review', Frontiers in Education Conference (FIE), 21-24 October, IEEE, El Paso, pp.1-8.

Brown, T.H. and Mbati, L.S. (2015) 'Mobile learning: moving past the myths and embracing the opportunities', The International Review of Research in Open and Distributed Learning, Vol. 16, No. 2, pp.115-135.

Cervera, M.G. and Johnson, L. (2015) 'Education and technology: new learning environments from a transformative perspective', RUSC Universities and Knowledge Society Journal, Vol. 12, No. 2, pp.1-13.

Chen, Y. (2015) 'Linking learning style and learning on mobile Facebook', International Review of Research in Open and Distributed Learning, Vol. 16, No. 2, pp.94-114.

Davidson, N., Major, C.H. and Michaelsen, L.K. (2014) 'Small-group learning in higher education - cooperative, collaborative, problem-based, and team-based learning: an introduction by the guest editors', Journal on Excellence in College Teaching, Vol. 25, Nos. 3-4, pp.1-6.

Faqih, K.M. and Jaradat, M.I.R.M. (2015) 'Assessing the moderating effect of gender differences and individualism-collectivism at individual-level on the adoption of mobile commerce technology: TAM3 perspective', Journal of Retailing and Consumer Services, Vol. 22, pp.37-52.

Farajollahi, M., Zandi, B., Sarmadi, M. and Keshavarz, M. (2015) 'Computer literacy in a distance education system', Australian Educational Computing, Vol. 30, No. 2, pp.14.

Fulantelli, G., Taibi, D. and Arrigo, M. (2015) 'A framework to support educational decision making in mobile learning', Computer in Human Behavior, Vol. 47, pp.50-59.

Furió, D., Juan, M.C., Seguí, I. and Vivó, R. (2015) 'Mobile learning vs. traditional classroom lessons: a comparative study', Journal of Computer Assisted Learning, Vol. 31, No. 3, pp.189-201.

Gan, C.L. and Balakrishnan, V. (2016) 'An empirical study of factors affecting mobile wireless technology adoption for promoting interactive lectures in higher education', International Review of Research in Open and Distributed Learning, Vol. 17, No. 1, pp.116-136. 
García-Peñalvo, F.J. and Conde, M.Á. (2015) 'The impact of a mobile personal learning environment in different educational contexts', Universal Access in the Information Society, 14, No. 3, pp.375-387.

Grimus, M. and Ebner, M. (2015) 'Learning and teaching with mobile device: an approach in higher secondary education in Ghana', International Journal of Mobile and Blended Learning, Vol. 7, No. 2, pp.16.

Gull, F. and Shehzad, S. (2015) 'Effects of cooperative learning on students' academic achievement', Journal of Education and Learning (EduLearn), Vol. 9, No. 3, pp.246-255.

Hằng, N.V.T., Meijer, M.R., Bulte, A.M. and Pilot, A. (2015) 'The implementation of a social constructivist approach in primary science education in Confucian heritage culture: the case of Vietnam', Cultural Studies of Science Education, Vol. 10, No. 3, pp.665-693.

Hasyim, K.F., Tan, F.B. and Rashid, A. (2015) 'Adult learners' intention to adopt mobile learning: a motivational perspective', British Journal of Educational Technology, Vol. 46, No. 2, pp.381-390.

Herman, W.E. and Pinard, M.R. (2015) 'Critically examining inquiry-based learning: John Dewey in theory, history, and practice', Inquiry-Based Learning for Multidisciplinary Programs: A Conceptual and Practical Resource for Educators, Emerald Group Publishing Limited, Bingley, pp.43-62.

Huang, Y.M. and Chiu, P.S. (2015) 'The effectiveness of a meaningful learning-based evaluation model for context-aware mobile learning', British Journal of Educational Technology, Vol. 46, No. 2, pp.437-447.

Huang, Y.H., Wu, P.H. and Hwang, G.J. (2015) 'The pilot study of the cooperative learning interactive model in e-classroom towards students' learning behaviors', 2015 IIAI 4th International Congress on Advanced Applied Informatics (IIAI-AAI), 12-16 July, IEEE, Okayama, pp.279-282.

Hwang, G.J. and Shih, J.L. (2015) 'Experiences of using a blended mobile learning approach to connect classroom and in-field learning activities in a local culture course', Seamless Learning in the Age of Mobile Connectivity, Springer, Singapore, pp.319-333.

Jacobs, G.M. (2015) 'Collaborative learning or cooperative learning? The name is not important; flexibility is', Beyond Words, Vol. 3, No. 1, pp.32-52.

Jansen, D., Schuwer, R., Teixeira, A. and Aydin, C.H. (2015) 'Comparing MOOC adoption strategies in Europe results from the HOME project survey', International Review of Research in Open and Distributed Learning, Vol. 16, No. 6, pp.94-114.

Kent, C., Laslo, E. and Rafaeli, S. (2016) 'Interactivity in online discussion and learning outcomes', Computer \& Education, Vol. 97, pp.116-128.

Kwan, Y.W. and Wong, A.F.L. (2015) 'Effects of the constructivist learning environment on students' critical thinking ability: cognitive and motivational variables as mediators', International Journal of Educational Research, Vol. 70, pp.68-79.

Lai, C. and Hwang, G. (2015) 'High school teachers' perspectives on applying different mobile learning strategies to science courses: the national mobile learning program in Taiwan', International Journal of Mobile Learning and Organisation, Vol. 9, No. 2, pp.124-145.

Lam, J. (2015) 'Collaborative learning using social media tools in a blended learning course', Hybrid Learning: Innovation in Educational Practices, Springer International Publishing, Wuhan, China, pp.187-198.

Land, S.M. and Zimmerman, H.T. (2015) 'Socio-technical dimensions of an outdoor mobile learning environment: a three-phase design-based research investigation', Educational Technology Research and Development, Vol. 63, No. 2, pp.229-255.

Lee, H.L., Parsons, D., Kwon, G., Kim, J., Petrova, K., Jeong, E. and Ryu, H. (2015) 'Cooperation begins: encouraging critical thinking skills through cooperative reciprocity using a mobile learning game', Computers \& Education, Vol. 97, pp.97-115. 
Looi, C.K., Sun, D. and Xie, W. (2015) 'Exploring students' progression in an inquiry science curriculum enabled by mobile learning', IEEE Transactions on Learning Technologies, Vol. 8, No. 1, pp.43-54.

Mehta, S. and Kulshrestha, A.K. (2014) 'Implementation of cooperative learning in science: a developmental-cum-experimental study', Education Research International, Vol. 2014, pp.1-7.

Mohammad, H., Fayyoumi, A. and Al Sahathry, O. (2015) 'Do we have to prohibit the use of mobile phone in classrooms?', International Journal of Interactive Mobile Technologies, Vol. 9, No. 2, pp.54-57.

Montrieux, H., Venderlinde, R., Schellens, T. and De Meres, L. (2015) 'Teaching and learning with mobile technology: a qualitative explorative study about the introduction of tablets devices in secondary education', PloS One, Vol. 10, No. 2, e0144008.

Muchlas, M. (2015) 'Developing a teaching model using an online collaboration approach for a digital technique practical work', TOJET: The Turkish Online Journal of Educational Technology, Vol. 14, No. 3, pp.63-69.

Powell, L.M. and Wimmer, H. (2015) 'Evaluating the effectiveness of student group work for mobile application development learning, productivity, enjoyment and confidence in quality', Proceedings of the EDSIG Conference (n3456), Wilmington, NC.

Pullen, D. (2015) 'The influence of the home learning environment on middle school students' use of ICT at school', Australian Educational Computing, Vol. 30, No. 1, pp.1-20.

Pullen, D., Swabey, K., Abadooz, M. and Ranjit Sing, T.K. (2015) 'Pre-service teachers' acceptance and use of mobile learning in Malaysia', Australian Educational Computing, Vol. 30, No. 1.

Reychav, I. and Wu, D. (2015) 'Mobile collaborative learning: the role of individual learning in groups through text and video content delivery in tablets', Computer in Human Behavior, Vol. 50, pp.520-534.

Salam, A., Hossain, A. and Rahman, S. (2015) 'The effect of using Teams Games Tournaments (TGT) cooperative technique for learning mathematics in secondary schools of Bangladesh', Journal of Research in Mathematics Education, Vol. 4, No. 3, pp.271-287.

Sarrab, M., Al-Shihi, H. and Khan, A.I. (2015) 'An empirical analysis of mobile learning (m-learning) awareness and acceptance in higher education', International Conference on Computing and Network Communication (CoCoNet), 16-19 December, Trivandrum, pp.960-963.

Sharan, Y. (2015) 'Meaningful learning in the cooperative classroom', Education 3-13, Vol. 43, No. 1, pp.83-94.

Shroff, R., Keyes, C. and Linger, W.S. (2015) 'A proposed taxonomy of theoretical and pedagogical perspectives of mobile application to support ubiquitous learning', Ubiquitous Learning: An International Journal, Vol. 8, No. 4, pp.23-44.

Srisawasdi, N. and Sornkhatha, P. (2014) 'The effect of simulation-based inquiry on students' conceptual learning and its potential applications in mobile learning', International Journal of Mobile Learning and Organization, Vol. 8, No. 1, pp.28-49.

Sulisworo, D. and Suryani, F. (2014) 'The effect of cooperative learning, motivation and information technology literacy to achievement', International Journal of Learning \& Development, Vol. 4, No. 2, pp.58-64.

Sung, Y., Chang, K. and Liu, T. (2016) 'The effects of integrating mobile device with teaching and learning on students' learning performance: a meta-analysis and research synthesis', Computer \& Education, Vol. 94, pp.252-275.

Sung, H., Jeong, D. and Shin, J. (2015) 'The relationship among self-efficacy, social influence, performance expectancy, effort expectancy, and behavioral intention in mobile learning service', International Journal of $u$ - and e-Service, Science and Technology, Vol. 8, No. 9, pp.197-206. 
Tadesse, T. and Gillies, R.M. (2015) 'Nurturing cooperative learning pedagogies in higher education classrooms: evidence of instructional reform and potential changes', Current Issues in Education, Vol. 18, No. 2, pp.16.

Yau, H.K. and Leung, Y.F. (2016) 'Gender difference of self-efficacy and attitudes towards the use of technology in learning in Hong Kong higher education', Proceedings of the International MultiConference of Engineers and Computer Scientists, 16-18 March, Hong Kong.

Zagami, J. (2015) 'An analysis of 27 years of research into computer education published in Australian educational computing', Australian Educational Computing, Vol. 30, No. 1. Available online at: http://journal.acce.edu.au/index.php/AEC/article/view/63 